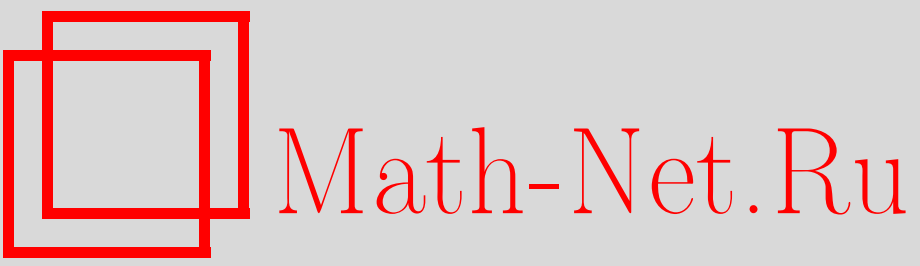

15 Международная конференция по нелинейным эволюционным уравнениям и динамическим системам, ТМФ, 2003, том 134, номер 1, 3-4

DOI: https://doi.org/10.4213/tmf1917

Использование Общероссийского математического портала Math-Net.Ru подразумевает, что вы прочитали и согласны с пользовательским соглашением

http://www.mathnet.ru/rus/agreement

Параметры загрузки:

IP : 35.173 .219 .149

26 апреля 2023 г., 12:49:54 


\section{5 Международная конференция по нелинейным эволюционным уравнениям и динамическим системам}

В данном выпуске мы завершаем публикацию трудов 15 Международной конференции "Нелинейные эволюционные уравнения и динамические системы" (NEEDS 2001).

В т. 133, № 2 были опубликованы следующие доклады:

$\Phi$. Калоджеро. Разрешимая задача трех тел и гипотезы Пенлеве

О. Костин, М. Крускал. Подвижные особые точки решений разностных уравнений, их связь с разрешимостью и исследование сверхстабильных фиксированных точек

А. Дегасперис, Д. Д. Холм, А.Н. И. Хон. Новое интегрируемое уравнение с пиконными решениями

А. Дегасперис, С. В. Манаков, П. М. Сантини. Смешанные задачи для линейных и солитонных уравнений в частных производных

П. Г. Эстевес, Ч.-Ж. Чу. Разделение переменных в нелинейных волновых уравнениях с переменной волновой скоростью

М. Гехтман, А. Касман. Интегрируемые системы и условия одноранговости для прямоугольных матрищ

$\Phi$. Женье, Ж. Леон. Спектральное преобразование Захарова-Шабата на полупрямой

Р. Эрнандес Эредеро. Интегрируемые квазилинейные уравнения

Б. Конопельченко, Л. Мартинес Алонсо, Е. Медина. Квазиконформные отображения и решения бездисперсионной иерархии КП

С. Ломбардо. Обратное спектральное преобразование для $q$-деформированного уравнения Вольтерра

И. Лорис. Билинейные представления интегрируемых уравнений

О.И. Мохов. Согласованные гамильтоновы операторы Дубровина-Новикова, производная Ли и интегрируемые системы гидродинамического типа

С. Мурьель, Х. Л. Ромеро. Продолжения векторных полей и свойство сушествования инвариантов, получаемых посредством дифференцирования

М. Нешпорски. Лестничная диаграмма Лапласа дискретных уравнений лапласова типа

М. Педрони, В. Шиача, Х. П. Зубелли. Бигамильтонова теория уравнения Гарри Дима

Б. Пеллони. О корректных граничных задачах для интегрируемых эволюционных уравнений на конечном интервале 
В т. 133, № 3 были опубликованы следующие доклады:

Р. Балакришнан, С. Муругеш. Кинематика трех подвижных пространственных кривых, связанных с нелинейным уравнением Шредингера

Дж. Г.Б. Байатт-Смит, Г.У. Браден. О функциональном уравнении Руджинарса

Р. Билс, Д.Х. Саттинджер, Й. Шмигельски. Потоки Калоджеро-Франсуаза и периодические пиконы

С. Босколо, С. К. Турищын, В. Ю. Новокшенов, Й. Х. Б. Нийхоф. Самоподобные параболические оптические уединенные волны

Ю. В.Брежнев. Конечнозонные потенциалы с тригональными кривыми

К.Р. Гилсон. Обобщение иерархий КП: пфаффианизованные иерархии

Х. Какухата, К. Конно. Врашаюшийся петлевой солитон в связанных бездисперсионных уравнениях

Л.А. Калякин. Асимптотическое решение задачи об авторезонансе

Ю. Кодама. Топология вешественной части гиперэллиптического якобиана, связанного с периодической решеткой Тоды

М. Маньяс, Л. Мартинес Алонсо, Е. Медина. Редукции бездисперсионной иерархии КП

М. Педрони. Бигамильтоновы аспекты разделимости переменных в системе Неймана

В. В. Соколов, А. В. Цыганов. Коммутативные пуассоновы подалгебры для скобок Склянина и деформации известных интегрируемых моделей 